\title{
40. THE GUATEMALAN MARGIN, THE NICOYA COMPLEX, AND THE ORIGIN OF THE CARIBBEAN PLATE ${ }^{1}$
}

\author{
Jacques Azéma, Département de Géotectonique, Université Pierre et Marie Curie, 75230 Paris Cedex 05, France \\ and \\ Jean Tournon, Laboratoire de Pétrologie, Université Pierre et Marie Curie, 75230 Paris Cedex 05, France
}

\section{INTRODUCTION}

One of the most important aims of the DSDP Leg 67 investigation of the Middle America Trench off Guatemala was to test for and, if possible, confirm the existence of an accretionary prism in an active margin that constitutes a classic example of a Benioff zone and is characterized by a high rate of subduction $(10 \mathrm{~cm} / \mathrm{yr}$.).

We had planned a series of deep drill holes on the platform and continental slope along a transect perpendicular to the Trench axis, in depths ranging from 1600 to 5500 meters (Fig. 1A and B). We chose this area because previous detailed geophysical work suggested that the continental platform is underlain by widespread Tertiary sediments overlying deformed older sequences, including sheets of basic and ultrabasic rocks (Fig. 1C) (Ladd et al., 1978). This interpretation is supported by a strong magnetic anomaly bordering the continental platform (Fig. 2) and aligned with the Nicoya and Santa Elena peninsulas of Costa Rica (Woodcock, 1975; Couch, 1976; Ladd et al., 1978), where Mesozoic volcanic rocks and sediments (the Nicoya Complex) and ultrabasic rocks, thought to represent mainly oceanic crust, are exposed (Dengo, 1962b, 1973; Weyl, 1966; Henningsen and Weyl, 1967; Pichler et al., 1974; Stibane et al., 1977; de Boer, 1979; Galli, 1979; SchmidtEffing, 1979; Azéma and Tournon, 1980; Kuÿpers, 1980).

Unfortunately, the presence of abundant gas in the drill holes prevented accomplishment of the original aim -drilling at Sites 496, 497, and 498 had to be stopped. For reasons of safety drilling at the other planned sites on the slope and platform was also abandoned.

Thus Leg 67 did not provide direct evidence for the presence of old oceanic sediments off Guatemala. The presence in this area of rocks equivalent to the Nicoya Complex is probable but remains a hypothesis.

\section{THE UPPER CRETACEOUS-PALEOGENE SEDIMENTARY COVER: INFORMATION FROM SITE 494 AND INLAND OBSERVATIONS}

Drilling at Site 494 , on a topographic bench at the base of the slope, yielded results unexpected for a location so near the Trench axis, where we expected to find structures corresponding to an accretionary prism (Seely et al., 1974). At this site, under more than 5500 meters

${ }^{1}$ Aubouin, J., von Huene, R., et al., Init, Repts. DSDP, 67: Washington (U.S. Góvt. Printing Office) of water, we drilled a continuous normal succession about 350 meters thick, in which the oldest beds are Upper Cretaceous (upper Campanian-Maestrichtian) and overlie basalts. The pelagic facies of the middle Eocene, lower Miocene, Pliocene, and Pleistocene become progressively more terrigenous upwards. This sequence, except for minor differences in thickness, is very similar to that of the Esso Petrel well on the continental platform off Guatemala (Seely, 1979).

The succession at Site 494 is, on the other hand, very different from that cored in the Cocos Plate at Site 500 -less than $3 \mathrm{~km}$ to the west and 400 meters deeper than Site 494-where lower Miocene directly overlies ocean-crust basalts.

On land, along the Pacific shore of Nicaragua, Costa Rica, and Panama, a thick sedimentary sequence is exposed, starting with an upper Campanian-Maestrichtian conglomerate (exposed locally at Santa Elena) and followed by Tertiary clastic facies rich in volcanic, commonly andesitic components. The sequences at Site 494 and along the shore, although different in facies and in thicknesses, have one characteristic in common: both show an unconformity between Late Cretaceous and thick Tertiary deposits. The abundant volcanogenic detritus in the Tertiary formations must be attributed to the inception, starting in the Paleocene, of an andesitic volcanic arc in southern Central America. Compared to the Tertiary sequences in Nicaragua and Costa Rica, which are close to the source area for the volcanogenic detritus, the sequence at Site 494 shows a more distal, more abyssal facies.

\section{MESOZOIC OCEAN-CRUST REPRESENTATIVES ON THE PACIFIC SHORE OF COSTA RICA}

Given the failure of the planned drill holes to reach a deformed complex of "ancient" volcaniclastic beds and sheets of basic and ultrabasic rocks, whose presence off Guatemala is suggested by geophysical data, the true structure of the continental margin remains hypothetical. Nevertheless, the study of possible ocean-crust assemblages cropping out in Costa Rica, mainly in the Nicoya and Santa Elena peninsulas (Fig. 3), may partly make up for the lack of cores.

\section{Nicoya Peninsula}

Dengo (1962a) introduced the name "Nicoya Complex" for a deformed volcaniclastic unit that occurs at the base of a thick, mainly clastic, Tertiary sequence; 

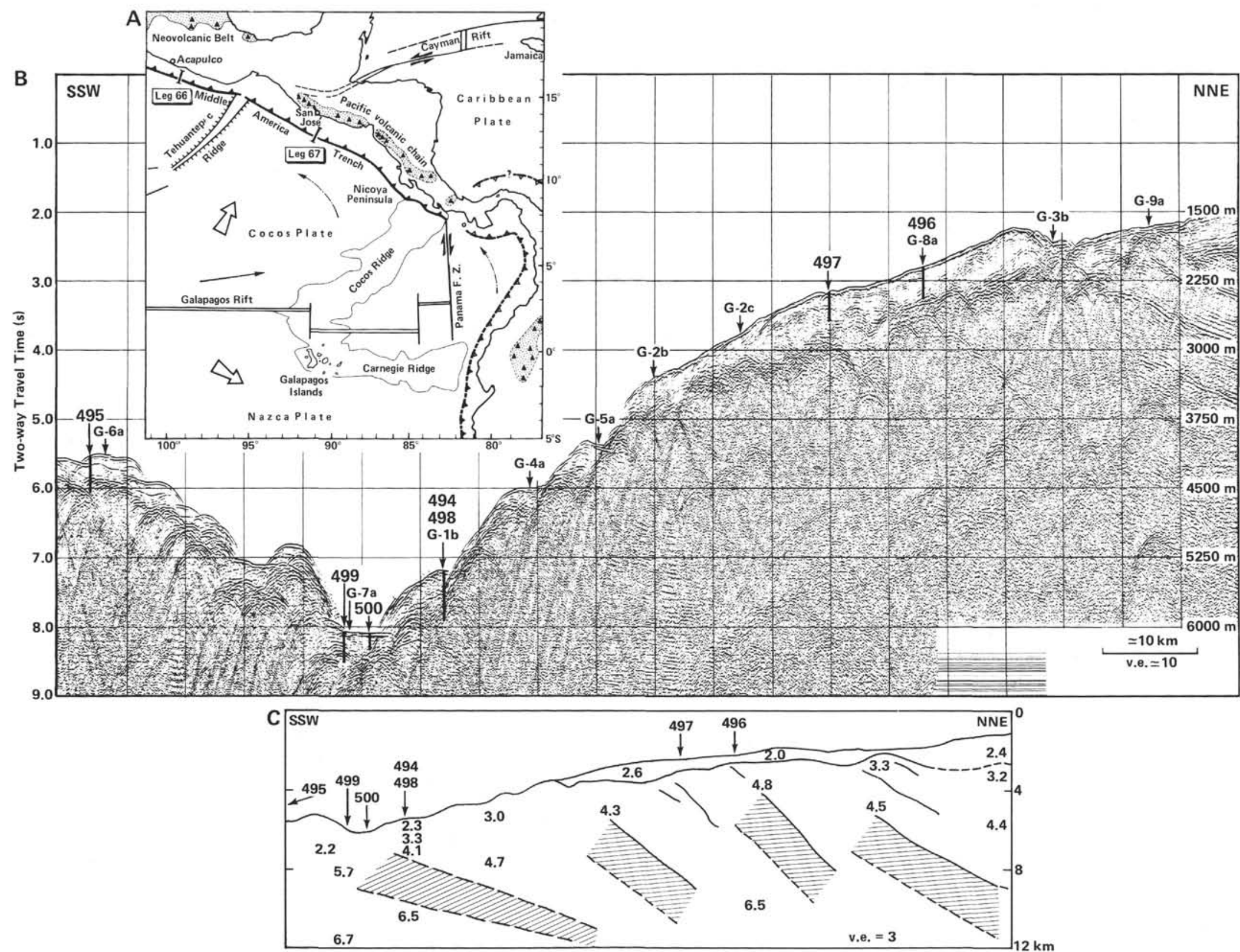

Figure 1. A. Location of Leg 67. B. Multichannel seismic profile (Guatemala 13) run by the Marine Institute of the University of Texas (Ladd et al., 1978). (Note the extensional character of the Trench, in particular the small graben on the seaward wall and the benches on the landward wall.) C. Interpretation of profile in Figure 1B (Ladd et al., 1978). (Numbers indicate $P$-wave velocities $[\mathrm{km} / \mathrm{s}]$. Shadowed areas are presumed ophiolite slabs.) 


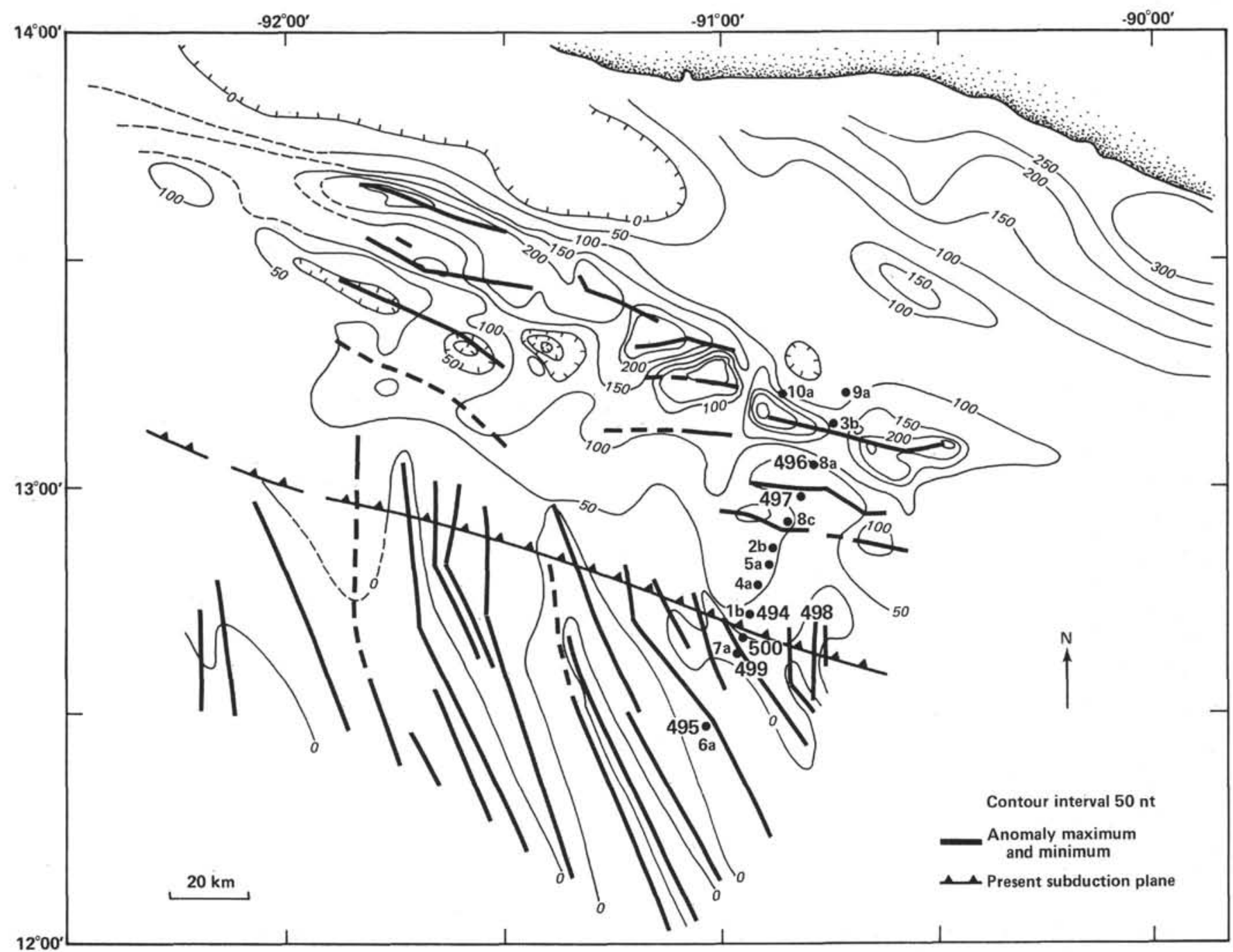

Figure 2. Magnetic anomalies on the continental slope and on the Cocos Plate seaward of Guatemala (after Ladd et al., 1978).

the age of this volcaniclastic unit, although uncertain, is clearly older than Late Cretaceous (late CampanianMaestrichtian). The Nicoya Complex is formed of massive and pillow basalt, associated with jasper and chert in some places rich in manganese, tuff, graywacke, and more or less silicified breccia. Radiolarian biostratigraphy shows that there are at least two basalt-chert episodes: one during the Early Cretaceous (BerriasianAptian), the other in the Late Cretaceous (early Santonian) (Kuÿpers, 1980). The presence of Upper JurassicLower Cretaceous cherts has been reported (Galli, 1977; Schmidt-Effing, 1979). Futhermore, ammonites indicate the presence of upper Albian rocks (Azema et al., 1979). A thick suite of dolerites, occasionally differentiated, is present only within the lower Santonian basalt-chert sequence (Kuÿpers, 1980). Radiometric measurements of pillow lavas indicate an age of $72.5 \pm 4.0$ m.y. (Barr and Escalante, 1969). According to Schmidt-Effing (1979), the top of the Nicoya Complex would be Paleocene-Eocene.
As the Nicoya Peninsula has not yet been completely mapped in detail, it is difficult to establish the age relationships between the different lithologies; several hypotheses have been proposed to explain their presence in the Nicoya Complex:

1) Accretionary prism (Galli, 1979);

2) Continuous sedimentation from the Latest Jurassic to the Paleocene-Eocene on an aseismic ridge (Schmidt-Effing, 1979);

3) Polyphase mechanism involving obduction of an ocean-crust assemblage (Nicoya Complex s.s.) in the early Coniacian, followed by a mainly volcanic episode affecting the Nicoya Complex (de Boer, 1979);

4) Overthrusting of an ocean-crust assemblage during the Cenomanian to early Santonian (Esperanza unit) onto an older ocean-crust assemblage that contains an Early Cretaceous radiolarian fauna (Matapalo unit) (Kuypers, 1980).

It seems, then, premature to attempt a conclusive account of the structure of this region complicated by Ter- 


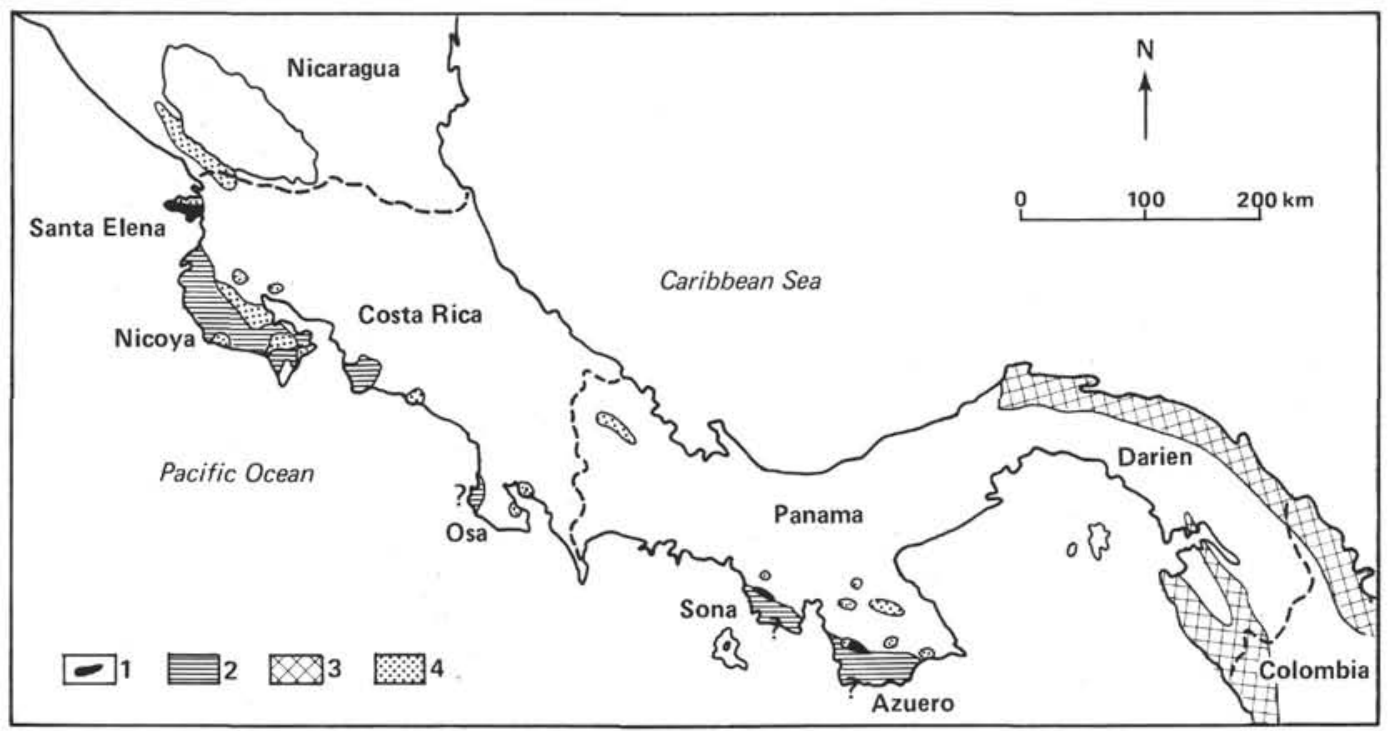

Figure 3. Location of Santa Elena ophiolites (1) and Sona-Azuero greenschists (1), Nicoya Complex Mesozoic rocks (2), Darien Late Cretaceous volcano-sedimentary oceanic(?) formations (3), and upper CampanianMaestrichtian sedimentary outcrops of southern Central America (4). (? indicates that the presence of Nicoya Complex rocks in these three places is only a possibility.)

tiary overthrusts and faults that disturb, transform, and mask the older deformation in the Nicoya Complex.

\section{Santa Elena Peninsula}

Santa Elena contains the only known remnant of ultrabasic rock (basal part of an ophiolite sequence) in southern Central America (Harrison, 1953; Dengo, 1962a and 1962b; Azéma and Tournon, 1980) and shows good outcrops of a complex structural edifice assembled before the late Campanian-Maestrichtian.

Schematically, this massif shows, from base to top (Fig. 4): a lower, relatively autochthonous sequence formed by basic volcaniclastic rocks; a megabreccia assemblage; an upper allochthonous unit formed by ultrabasic rocks; an Upper Cretaceous-Paleogene sedimentary cover with, at the base, a conglomerate containing clasts of ultrabasic rocks, which, in turn, grades upward to a thick Tertiary clastic succession.

The lower unit is exposed in a window in a valley within the massif and in a half-window on the southern shore of the Peninsula. The volcaniclastic rocks are massive and pillow basalts, dolerite, chert with occasional intercalations of black schist, graywacke, and dikes. Radiolarians indicate that at least part of the chert may be Cenomanian (Schmidt-Effing, 1980).

The megabreccia assemblage is exposed on the southern shore at Playa Carrizal, Playa Santa Rosa, Playa Respingue, and Playa Naranjo and shows a chaotic unit with blocks of dolerites, gabbros, and less commonly radiolarian cherts, a few meters to tens of meters long, embedded in a matrix of sheared serpentinite. Locally, plagiogranites have been found as clasts (Playa Naranjo); they were probably derived from erosion of this megabreccia assemblage.

The upper unit (about $300 \mathrm{~km}^{2}$ ) is essentially formed by more-or-less serpentinized harzburgitic peridotite showing relicts of olivine, orthopyroxene, brown spinel, and, less frequently, clinopyroxene. The peridotite is usually coarsely foliated with thick bands of pyroxenoliths parallel to the foliation. The ultrabasic rocks are cut, on the one hand, by sparse dikes of pegmatitic gabbro a few centimeters thick and lacking chilled margins. Additionally, there are numerous dikes 1- to 5-meters thick with chilled margins of dolerite (plagioclase, green hornblende, occasional relicts of clinopyroxene). In the western part of the peninsula between Playa Blanca and Playa Gringos, the coastal cliffs are mostly formed by dolerite dikes showing multiple intrusions (dike swarm). These dolerites, which are identical to those in other parts of the massif, show chilled margins at the contact with inclusions of serpentinized peridotite and pegmatitic gabbros up to 1 meter in size. At Bahia Nancite in the southern part of the peninsula, there are outcrops of a stratified complex of coarse-grained rocks with cumulate structure: melanocratic facies with olivine and idiomorphic clinopyroxene, poikilitic orthopyroxene, intercumulus plagioclase; and mesocratic facies with clinopyroxene, amphibole, plagioclase. This complex is cut by two dike systems: uralitized dolerites and extensively altered basalts with porphyric microlitic texture.

Few rocks in this complex show unmodified original paragenesis (serpentinization of the peridotites, uralitization of the basic rocks). In addition, there are several local exposures of foliated amphibolite showing microfolds (axial-plane schistosity), with calcic plagioclase and dark green hornblende representative of ancient dolerite dikes. At Rio Murcielago and Playa Gringos, rocks show calcium-rich levels with anorthite, diopside, and sphene. On the western shore, the thin plagioclase-hornblende dikes cut the foliated amphibolite, suggesting injection of basic magma after a phase of deformation. 


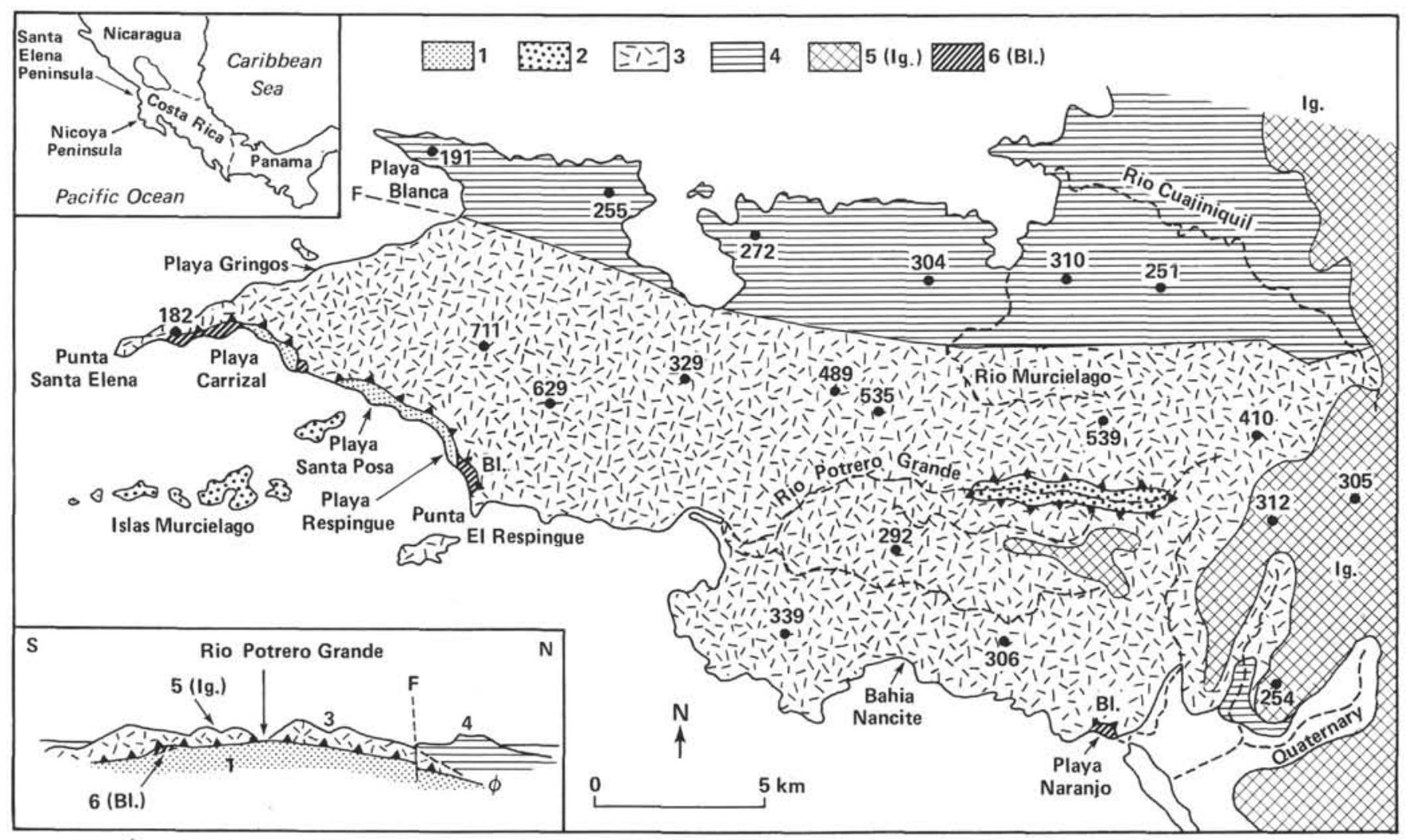

Figure 4. The Santa Elena Peninsula: index map and simplified structural cross-section. (1: lower volcaniclastic unit; 2: pillow lava of the Murcielago Islands; 3: upper ultrabasic and basic unit; 4: sedimentary cover; 5 (Ig.): ignimbrites; 6 (B1.): megabreccia assemblage. F: Murcielago fault. Numbers are topographic elevations in meters. $\phi=$ thrust plane.)

Finally, in the basic rocks there are local examples of low- to medium-temperature paragenesis: thin dikes with prehnite, and facies with zoisite, epidote, chlorite, and albite.

The Santa Elena ultrabasic massif is interpreted as a thin (less than 1000-m thick) overthrust unit showing deformed peridotite, pegmatitic gabbros in dikes, coarsegrained rocks with cumulate texture, doleritic dike swarms, that is, an assemblage characteristic of the lower part of an ophiolite sequence (Coleman, 1977).

Some important features of this massif are worthy of note:

1) Good development and high density of the doleritic dikes in the peridotite. bros.

2) Subordinate development of the cumulate gab-

3) Presence of amphibolites within the ophiolitic massif, formed as the result of metamorphism of basic rock along thin shear zones.

4) Presence of lava stringers that recut the dolerites; pillow lavas are now obscured.

These observations lead us to abandon the hypothesis that the Santa Elena ultrabasic massif is simply a horst of deep-seated rocks with their volcaniclastic cover locally preserved (Dengo, 1962a). The ultrabasic and basic rocks of the lower part of an ophiolite sequence in the upper unit of the Santa Elena Peninsula are without roots and belong to a sheet thrust upon a relatively autochthonous basic volcaniclastic unit, which is the prolongation or possible lateral equivalent of the Nicoya Complex. The direction and magnitude of the initial thrusting remain unknown.

According to de Boer (1979), the Santa Elena peridotites originated from an east-trending suture zone, located between the continental block formed by southern Central America and the oceanic plate to the south (which would include the Nicoya Complex s.s.); it is their outcrop exposure that delineates the western end of the suture.

\section{Conclusions}

Field mapping clearly shows that the Pacific coastal region in Costa Rica is underlain by deformed Mesozoic rocks (Upper Jurassic? to Upper Cretaceous) representing ocean crust. Although the structure of the Nicoya Complex is still uncertain, the presence in Santa Elena Peninsula of a complex involving a nappe of ultrabasic rocks suggests a similar interpretation for the Nicoya Peninsula, as has already been postulated by Kuÿpers (1980). The age of this major phase is probably older than late Campanian-Maestrichtian, although evidence for this age is at present restricted to the Santa Elena Peninsula.

\section{SIGNIFICANCE OF THE OFFSHORE AND ONSHORE RESULTS}

Doubt regarding the simple accretionary prism model, at least for the margin off Guatemala, is a major out- 
come of Leg 67 (Aubouin et al., 1979; von Huene et al., 1980 ), but other important results were achieved, especially from coring at Site 494.

A continous normal sequence ranging from Pleistocene to Uppermost Cretaceous at Site 494 suggests that this may be the lateral equivalent-despite differences in facies and in thicknesses-of the inland formations that form the cover of the Nicoya Complex. The sequence at Site 494 would be more distal.

The Uppermost Cretaceous facies found at Site 494 also occurs from southwestern Nicaragua to Panama and possibly on the west coast of Colombia (Goossens et al., 1977). Its presence offshore Guatemala rules out the possibility of the Caribbean Plate having a Pacific origin from that date onwards, as Malfait and Dinkelman (1972) have suggested.

In the absence of data regarding the initiation of tectonism at the paleolatitude of the Nicoya Complex and the mode of emplacement of the ultrabasic rocks of Santa Elena now exposed on land, the uncertainty of assigning a Pacific origin to the Caribbean Plate offers some interesting alternatives (Aubouin and Azéma, 1980). The Caribbean region could have been part of the westernmost Tethys Ocean during the Mesozoic (Aubouin et al., 1977) and subsequently isolated from it by the opening of the Atlantic.

The interpretation that the pre-late Campanian-Maestrichtian formations exposed in the Santa Elena and Nicoya peninsulas of Costa Rica are ocean-crust representatives derived either from the Pacific or from a "marginal" basin is generally accepted, but the structure of the Nicoya Complex remains hypothetical. A nappe structure is probable, and this hypothesis, as proposed by Kuÿpers (1980), is strongly supported by the presence of an ultrabasic overthrust unit in the Santa Elena Peninsula. These rocks, representing the lower part of an ophiolite sequence, are crucial evidence for the existence of a subduction zone during the Mesozoic in this Pacific region.

Given the absence in southern Central America of volcanic rocks or sediment suggesting the existence of an emergent terrane or even the existence of an island arc before the Latest Cretaceous, we must consider the possibility of an intraoceanic origin of the older members in the Nicoya Complex and Santa Elena massif. ${ }^{2}$

Subsequently, vertical movements generated in front of the Cocos Ridge were probably responsible for the uplift and emersion of part of these oceanic formations, on top of which reef-facies locally developed in the late Campanian-Maestrichtian. Later, in the early Eocene or even the Paleocene, andesitic volcanics followed, suggesting the development of a volcanic arc between the North America and South America continents, that is, an eastward subduction of the Cocos Plate.

\section{ACKNOWLEDGMENTS}

We wish to thank J. R. Kienast and C. Grandjacquet for interesting comments and discussions about petrography and tectonic prob-

\footnotetext{
${ }^{2}$ But this hypothesis must be reconsidered in light of the existence of a thick sedimentary sequence deposited from the Cenomanian to the Maestrichtian that has been discovered in southern Nicaragua (Tax Improvement and Natural Resources Inventory Project, 1972). It
} will be very important to confirm this crucial fact. lems related to ophiolites. We thank G. Bonorino for the English translation. The field investigations in Costa Rica and Panama were supported by the Centre National de la Recherche Scientifique by way of the A.T.P. IPOD No. 37.66.

\section{REFERENCES}

Aubouin, J., and Azéma, J., 1980. A propos de l'origine de la plaque caraibe: la face pacifique de l'Amérique centrale. C. R. Acad. Sci. Ser. D, 291:33-37.

Aubouin, J., Blanchet, R., Stephan, J. F., and Tardy, M., 1977. Téthys (Mésogée) et Atlantique: données de la géologie. C. R. Acad. Sci. Ser. $D, 285: 1025-1028$.

Aubouin, J., von Huene, R. E., et al., 1979. Premiers résultats des forages profonds dans le Pacifique au niveau de la fosse du Guatemala (fosse d'Amérique centrale) (Leg $67 \mathrm{du}$ "Deep Sea Drilling Project" mai-juin 1979). C. R. Acad. Sci. Ser. D, 289:1215-1220.

Azéma, J., Sornay, J., and Tournon, J., 1979. Decouverte d'Albien supérieur à Ammonites dans le matériel volcano-sédimentaire du "complexe de Nicoya" (province de Guanacaste, Costa Rica). C. $R$. Sommaires Soc. Geol. Fr., fasc. 3:129-131.

Azéma, J., and Tournon, J., 1980. La Péninsule de Santa Elena, Costa Rica: un massif ultrabasique charrié en marge pacifique de l'Amérique centrale. C. R. Acad. Sci. Ser. D, 290:9-12.

Bandy, O. L., and Casey, R. E., 1973. Reflector horizons and paleobathymetric history, eastern Panama. Geol. Soc. Am. Bull., 84: 3081-3086.

Barr, K. W., and Escalante, G., 1969. Contribucion al esclarecimiento del problema de la edad del complejo de Nicoya, Costa Rica. Publ. Geol. ICAITI, 2:43-47.

Coleman, R. G., 1977. Ophiolites: Berlin-Heidelberg-New York (Springer Verlag).

Couch, R., 1976. Estructuras del margen continental de Centro America y el desarollo de una hipotesis. In Perez-Rodriguez, R., SuarezZozaya, M. R. (Eds.), First Reunion Latino-Americano sobre Ciencia Tecnologia de los Océanos: Mexico (Secretaria de Marina Mexicana), pp. 120-139.

de Boer, J., 1979. The outer arc of the Costa Rican orogen (oceanic basement complexes of the Nicoya and Santa Elena peninsulas). Tectonophysics, 56:221-259.

Dengo, G., 1962a. Estudio geologico de la region de Guanacaste, Costa Rica. Inst. Geogr. Costa Rica, San José.

1962b. Tectonic-igneous sequence in Costa Rica. Geol. Soc. Am., (Buddington volume), pp. 133-161.

1973. Estructura geologica, historia tectonica y morfologia de America Central. Publ. Geol. ICAITI, (2nd ed.).

Galli, C., 1977. Edad de emplazamiento y periodo de acumulacion de la ofiolita de Costa Rica. Rev. Cien. Tec. Univ. de Costa Rica, $1: 81-86$.

1979. Ophiolite and island-arc volcanism in Costa Rica. Geol. Soc. Am. Bull., 90:444-452.

Goossens, P. J., Rose, W. I., Jr., and Flores, D., 1977. Geochemistry of tholeites of the basic igneous complex of northwestern South America. Geol. Soc. Am. Bull., 88:1711-1720.

Harrison, J. V., 1953. The geology of the Santa Elena peninsula in Costa Rica, Central America. Proc. Pac. Sci. Congr. 7th, pp. $102-114$.

Henningsen, D., and Weyl, R., 1967. Ozeanische kruste im NicoyaKomplex von Costa Rica (Mittelamerika). Geol. Rundsch., 57: 33-47.

Kuÿpers, E., 1980. The geological history of the Nicoya ophiolite complex, Costa Rica, and its geotectonic significance. Tectonophysics, 68:233-255.

Ladd, J. W., Ibrahim, A. K., McMillen, K. J., Latham, G. V., von Huene, R. E., Watkins, J. E., Moore, J. C., and Worzel, J. L., 1978. Tectonics of the Middle America Trench offshore Guatemala. Int. Symp. of the Guatemala 4 February Earthquake and Reconstruction Process, Guatemala City, May 1978 (Vol. 1.)

Malfait, B. T., and Dinkelman, M. G., 1972. Circum-Caribbean tectonic and igneous activity and the evolution of the Caribbean Plate. Geol. Soc. Am. Bull., 83:251-272.

Pichler, H., Stibane, F. R., and Weyl, R., 1974. Basicher magmatismus und krustenbau im südlichen Mittelamerika, Kolumbien und Ecuador. Neues Jahrb. Palaeontol. Monatsh., 2:102-126. 
Schmidt-Effing, R., 1979. Alter und genese des Nicoya-Komplexes, einer ozeanischen Paläokruste (Oberjura bis Eozän) im südlichen Zentralamerika. Geol. Rundsch., 68(2):457-494.

1980. Radiolarien der Mittel-Kreide aus dem Santa Elena Massiv von Costa Rica. Neues Jahrb. Geol. Palaeontol. Abh., 160 (2):241-257.

Seely, D., 1979. Geophysical investigations of continental slopes and rises. In Watkins, J. S., and Montadert, L. (Eds.), Geological and Geophysical Investigation of Continental Margins: Tulsa, Oklahoma (Am. Assoc. Pet. Geol.). Memoir 51.

Seely, D., Vail, P. R., and Walton, G. G., 1974. Trench-slope model. In Burk, C. A., and Drake, C. L., (Eds.), The Geology of Continental Margins: New York (Springer Verlag), pp. 249-260.

Stibane, F. R., Schmidt-Effing, R., and Madrigal, R., 1977. Zur stratigraphisch-tektonischen entwicklung der halbinsel Nicoya (Costa
Rica) in der zeit von ober-kreide bis untertertiär. Giessener Geol. Schr., Festschrift Richard Weyl, 12:315-358, Giessen.

Tax Improvement and Natural Resources Inventory Project, 1972. The Geology of Western Nicaragua. Final Technical Report (Vol. IV): Managua, Nicaragua.

Ulloa, F., 1977. Aspectos geologicos de la parte este de la peninsula de Santa Elena (desde Cuajiniquil hasta Santa Rosa de la Cruz de Guanacaste) [Tesis de grado]. Univ. de Costa Rica.

von Huene, R. E., Aubouin, J., et al., 1980. Leg 67: The Deep Sea Drilling Project Mid-America Trench transect off Guatemala. Geol. Soc. Am. Bull., 91:421-432.

Weyl, R., 1966. Ozeanische kruste im südlichen Mittelamerika? Neues Jahrb. Geol. Palaeontol. Monatsh., pp. 275-281.

Woodcock, S. F., 1975. Crustal Structure of the Tehuantepec Ridge and adjacent continental margins of southwestern Mexico and western Guatemala [Master's dissert.]. Oregon State University. 